\title{
The Information of
}

\section{Needs of Historians}

\begin{abstract}
This article reports the results of a survey of historians in different fields of history. It includes information on the formats from which they get their information, where they find relevant references, and how they use materials in foreign languages. The results are compared with those found in other surveys and with citation studies.
\end{abstract}

\section{$A$}

LTHOUGH SCHOLARLY COMMUNICATION has only recently been recognized as a branch of research in its own right, interest in what scholars use and how they find out about it goes back many decades. Librarians realized early that in order to build their collections intelligently they needed to know the answers to such questions, and that answers had to be more than impressionistic. ${ }^{1}$ With the phenomenal increase in volume of publication, the financial constraints libraries have suffered and the sharp cutback in some kinds of publishing, especially book publishing, attention to all phases of scholarly communication has expanded greatly.

Attention has not, however, been evenly distributed: the natural sciences were the earliest and are still the most frequently studied fields. An imbalance was produced by greater availability of government funding in the natural sciences and the pressing nature of their problems: currency is crucial and the spectacular increase in quantity of publication appeared first in these fields. But the potential for improvement of bibliographical control and the recognition that the social sciences and humanities also have informational problems have attracted more work in these areas. This article is part of the effort to redress the balance.

Various approaches have been used to study information habits. The most common are the citation and the user study. Each contributes something different to our under-

Margaret F. Stieg is assistant professor, School of Library Service, Columbia University, New York City. standing of a field: the citation study shows what the writer has actually used; the user study reports the impressions of the information consumer. Each has drawbacks. Citation studies can only analyze what is actually cited, which is usually only a small portion of what is used. Citation studies cannot show relative importance among sources. Surveys depend upon an individual's memory, which may be faulty. All methods are limited to studying what the scholar has already discovered; they must work with what he has seen, not with what he ought to have seen.

Some research has been conducted that is either relevant to historians' information use or deals with it directly. Two British surveys, the Bath University project on social scientists $^{2}$ and a survey of humanists done at the University of Sheffield, ${ }^{3}$ included historians, but the Bath survey limited itself to economic historians. In the United States, the Joint Committee on Bibliographical Services to History conducted a small survey of historians that produced some limited results in the late $1960 \mathrm{~s} .^{4}$ A serial use survey studied information patterns of social scientists at the University of Illinois from a slightly different perspective. ${ }^{5}$ Two articles, one of social science citation studies ${ }^{6}$ and one of humanities use studies, ${ }^{7}$ summarized work that had been done and provided comparative data, although, interestingly, both excluded history. The study of the humanities obviously considered history a social science, the study of the social sciences considered it one of the humanities. There are at least two citation studies of history, one of American history ${ }^{8}$ and one of English history. ${ }^{9}$ 
This article is based upon a questionnaire sent to 767 historians listed in the Directory of American Scholars ${ }^{10}$ for a book just completed on historical periodicals. ${ }^{*}$ The primary purpose of the questionnaire was to ask for information on historians' use of and attitudes toward periodicals. Additional information on other aspects of their informationseeking habits was also sought, on the assumption that you might just as well bother people for more as for little. The questionnaire used many of the same questions asked by the Bath University group, so that comparable results would be obtained. When the questionnaires that could not be delivered were subtracted from the total, the response rate was close to 50 percent. They were divided into subject groups (table 1) and all responses were organized by these groups.

The respondents and the nonrespondents were very similar in nearly all respects. With an occasional exception, such as an underrepresentation of European history scholars among the respondents, the distribution of specializations was very similar. They come from similar institutions; by coincidence 13.4

\section{TABLE 1}

\section{RESPONSES}

\begin{tabular}{lc}
\hline \hline Subject & $\begin{array}{c}\text { Number of } \\
\text { Responses }\end{array}$ \\
\hline United States Topical $^{*}$ & 31 \\
United States Colonial Period $^{\text {United States Nineteenth Century }}$ & 31 \\
United States Twentieth Century & 29 \\
United States General & 27 \\
Art/Architecture & 43 \\
Miscellaneous $†$ & 20 \\
Music & 14 \\
Science/Technology & 10 \\
Europe General & 13 \\
Great Britain & 16 \\
Continental Europe & 21 \\
Eastern Europe $\$$ & 16 \\
Medieval & 13 \\
Classical & 19 \\
Far East & 7 \\
Middle East & 14 \\
Africa & 6 \\
India & 5 \\
Canada & 2 \\
Oceanic & 3 \\
Latin America & 19 \\
\hline
\end{tabular}

-For Example, United States social history, United States diplomatic history.

†Includes such specialties as oral history, archaeology, children. IIncludes Germany.

§Includes Austria-Hungary.

*The questionnaire was financed by a grant from the Spencer Foundation. percent of respondents and 13.4 percent of nonrespondents are at universities considered to have the top twenty-five graduate programs in history. ${ }^{11}$ In both groups, the remainder are predominately at other universities and colleges, but there are also some who are employed by historical societies, archives, and branches of the United States government. There are, too, some who are not employed. The likeness of employing institutions is important because it means that library services available to the two groups are also reasonably alike.

There are, however, two characteristics that are somewhat different. One of these is age. Younger historians were more likely to respond. The age distribution for respondents was $31-40$ years old, 30.2 percent; 41-50, 31.1 percent; and 51 or over, 36.6 percent. For nonrespondents the percentages were 17.0 percent, 26.3 percent and 56.7 percent. The two groups also differed in scholarly productivity. Of the respondents, 50.4 percent had written at least two books, five articles, or four articles and one book. Only 44.1 percent of the nonrespondents had done so.

The effect of these differences on the results of the survey cannot be stated with total assurance. Are, for instance, older scholars better trained bibliographically than younger ones? The older historians were graduate students during a time when graduate programs were smaller and offered more individual attention. Librarians' professional attitudes, on the other hand, have changed considerably over the past decades and there is a good chance that the younger historians were exposed to more bibliographical instruction. One result of these differences that does seem clear, however, is that the respondents . tended to be more active library users. Their greater productivity and their relative youth indicates this. Younger historians still have their way to make in the scholarly world, a way that is made through publication.

Table 1 illustrates an important fact about history that greatly influences the information-seeking patterns of historians: history is really an umbrella term covering a wide variety of specializations that have little in common with each other but their method. As the Behavioral and Social Sciences Survey put it: "History is no different from other intellectual disciplines in having 
to fulfill several roles at once; but it is more multifarious and hence more divided than most." 12 Another fact that has profound implications for their information seeking is that every subject has its historical aspect. This is perhaps best explained with a specific example using periodicals. If, for example, a historian is interested in the ecclesiastical history of seventeenth-century Somerset, he can expect to find related material published in professional scholarly historical journals (the general and those devoted exclusively to British history), those that publish local history of Somerset, and church and religious periodicals. As if that were not enough, articles can also appear in general-interest periodicals, since history is considered suitable fare for the average man. The bibliographic control over these four streams is by and large organized separately into (1) bibliographies or indexes that list scholarly historical publications, (2) those that cover local history, (3) those that concern church materials, and (4) those that are used for general, nonscholarly periodicals. Books present similar problems. The divisions are not absolute (occasionally one can find a bibliography devoted to seventeenthcentury Somerset ecclesiastical history), but they do exist and tend to be similar in most fields of history.

The historians queried were asked to rate on a scale of one to five (five indicating most used) their use of a variety of formats in their current research. Next, they were asked to identify the two most convenient and the two least convenient formats. They were then asked to briefly explain why the formats were inconvenient. The results are summarized in table 2.

Many of these results need no comment, but the lack of use of newer forms of media by historians is striking, if not surprising. Books and periodicals are used most heavily because these are where historical research usually appears. ${ }^{13}$ As several respondents pointed out, little relevant information is available in, for example, film or videotape. This is, of course, perfectly true if one is talking about the Renaissance, but even in areas such as twentieth-century United States history, where some relevant material could be found, historians are generally not interested in using it for research. The only exceptions to this group are the art historians who use pictorial sources and the music historians who use tape or other sound recordings. Another exception to the general evenness of response was in the area of government documents. All varieties of United States historians used them more than those in other kinds of history. This is doubtless a function of the greater availability and better organization of United States government documents compared to those of other countries.

The explanations for why they found certain formats inconvenient were extremely illuminating since the answers often gave information about attitudes toward the library, work habits, and assumptions about scholarship. Several said that convenience was irrelevant; they would use whatever they needed to use - an admirable but probably unusual research habit. Each format presents its own set of problems, but the responses to

TABLE 2

Physical Formats

\begin{tabular}{|c|c|c|c|c|c|}
\hline & $\begin{array}{l}\text { Average } \\
\text { Use }\end{array}$ & $\begin{array}{c}\text { Most } \\
\text { Convenient }\end{array}$ & $\begin{array}{c}\text { Least } \\
\text { Convenient }\end{array}$ & $\begin{array}{c}\text { Rank Order } \\
\text { of Use in } \\
\text { Bath Survey }\end{array}$ & $\begin{array}{l}\text { Rank Order } \\
\text { of Use in } \\
\text { Stieg Survey }\end{array}$ \\
\hline Periodicals & 4.26 & 251 & 6 & 3 & 2 \\
\hline Books & 4.47 & 282 & - & 2 & 1 \\
\hline Manuscripts & 3.66 & 28 & 94 & 1 & 3 \\
\hline Research reports & 2.16 & 16 & 28 & 8 & 7 \\
\hline Theses, dissertations & 2.75 & 11 & 90 & 9.5 & 6.5 \\
\hline Newspapers & 2.97 & 23 & 59 & 9.5 & 4 \\
\hline Government publications & 2.75 & 21 & 25 & 6.5 & 6.5 \\
\hline Microcopies & 2.86 & 17 & 111 & 14 & 5 \\
\hline Maps & 2.10 & 2 & 17 & 13 & 9 \\
\hline Films (pictorial) & 1.37 & $=$ & 30 & 18 & 12 \\
\hline Other pictorial (e.g., photographs) & 2.11 & 7 & 25 & 15 & 8 \\
\hline Tape recording or sound recording & 1.55 & 2 & 31 & 17 & 10 \\
\hline Videotape & 1.19 & 1 & 42 & 19 & 13 \\
\hline Computer printouts & 1.51 & 6 & 37 & 12 & 11 \\
\hline
\end{tabular}

-Several formats were included in the Bath survey that were not included on this survey of historians. These included other physical formats (ranked fourth), collections (fifth), colleagues (tied for sixth), conferences (eleventh), and radio and television (sixteenth). 
maps, films, pictorials, tape recordings, and videotape will not be discussed separately here. For the most part, those who found those forms least convenient did not explain why. It is probable that they do not use them often enough to provide good reasons for their decisions.

Microfilm, on the other hand, produced an outburst of response, some of which can be called impassioned. The most common reasons cited for the inconvenience of this heavily used format were related to eyestrain and equipment. As one historian of early modern France said, "I hate microfilm - it makes me seasick to read it and bother my eyes. Librarians, gung ho for microfilms, rarely read the damned stuff." Another pointed out, "For every serious scholar eyes are too important and too susceptible to damage and fatigue to have to use backlighted and poorly screened film."

The cluster of equipment-related reasons had several facets. There is dislike of equipment per se, a feeling that it is an interposition between the scholar and his material. There is resistance to the fact that microfilm must be used in the library during library hours; it is plain that historians feel they have a right to work at home or in their offices. They do not find existing arrangements satisfactory: there is not enough space, and equipment is poor and always breaking down. Difficulties arise from the format: the film is not always of adequate quality (one historian referred to maddening dust spots and scars on the film); it provides only one exposure and one angle on problematic manuscript readings (this from a medieval historian); and, most often in this group of complaints, the fact that it is a roll. On a roll it is difficult to locate a single reference and the general custom of having endnotes rather than footnotes is particularly annoying. One historian expressed himself eloquently on this theme: "Microfilm has finally brought us full cycle to Alexandria. Having given up scrolls because we could not handle them (and did not want to handle them after indexing), we must now crank to the end of the scroll, back again, then back and forth." Another concurred; he would not endorse the displacement of the codex by the scroll. Several historians expressed the feeling that microfilm is fine for collecting data, but research is something more. The equipment and the format inhibit analysis and reflection. A number of scholars referred to the poor indexes and guides to microform sources. The art historians had a particular complaint: illustrations do not reproduce to their satisfaction. A historian of modern Germany wrote a paragraph that covers many of these points and provides food for thought:

Microfiche or microfilm is a pain to send, to find, to index and to reproduce. Libraries are making a major mistake by throwing out books in favor of filmstrips which are always deteriorating, readers breaking down, etc. Beware of the engineers! Card catalogues are far superior to online terminals, since human error is correctable in them!

The users of microfilm were analyzed by age to see if older historians had a greater reluctance to use this relatively new form. In fact, historians in the 51 or older category actually use microform somewhat more readily than their younger colleagues: their average use is 2.93 as opposed to the general average of 2.86. Like the younger historians, they do not let the fact that they find it inconvenient stop them from using it. It was noticeable that a number of historians who checked microform as one of their least convenient formats also circled the five for most used.

Manuscripts, the second most inconvenient format, present a very different set of problems. The largest of these is inevitable and derives from the uniqueness of manuscripts: they are located in only one place. A music historian spoke for many when he said, "They are located where I am not located." This problem is shared by all to a greater or lesser extent, including American historians. (A Colonial American historian pointed out that he was in Utah but the manuscripts he needed to consult were in Virginia.) Only rarely does microfilm provide a feasible alternative. Many scholars referred to the need for time and money. There is no doubt that the lack of both is a real obstacle to many historians. Manuscripts can also be difficult to read. (One European historian argued, however, that they are also fun.) Manuscripts can be difficult to locate. Guides and indexes are not considered adequate. And, once these obstacles are overcome and the scholar is actually with his material, there can be problems resulting from inadequate service. One American historian spoke of his need to use board of education and village government 
records, which were in the charge of people unaccustomed to serving the needs of serious researchers. Such difficulties are most acute in foreign repositories. One art historian mentioned a limit of three manuscripts per day and Russian historians struggle under even worse handicaps. It is difficult to gain access to Russian archives and yet the historian must, since Soviet institutions are rarely cooperative in making material available by mail.

The major problem with theses and dissertations, on the other hand, is the difficulty of obtaining them. Other difficulties arise from the fact that they, like newspapers, are often made available in microform, but those problems have already been discussed. Scholars attributed some of the difficulty in getting theses and dissertations to poor indexes, but more frequently they mentioned the mechanics of the process. University Microfilms has not solved the problems of theses and dissertations; historians find the arrangement both slow and costly. There are also important dissertation-producing institutions like Harvard, which do not participate in the Xerox (University Microfilms) plan. Several older historians, in fact, mentioned that the older system of depending on interlibrary loan had been preferable. As usual, those who need foreign materials have an even harder time. Often they cannot get what they need at all. And even if the scholar is successful in getting his desired dissertation, it often proves not worth the trouble. (This complaint was unique to this format.)

Newspapers, long a favorite source of information, also present major problems of procurement. According to the historians, they lack guides and especially indexes. They are practically never at the individual's own library or even, in the case of foreign newspapers, in the United States. When they are held, they are apt to be in an inconvenient location, like a storage library. They are "uncomfortable" to handle since they are bulky and tear easily.

The problems with other formats can be treated more briefly. With government publications, the usual difficulty mentioned was indexing. They are considered poorly indexed and even after a document is identified, the system of arrangement (presumably by Superintendent of Documents number) is too complicated for the scholar to use on his own. Multimedia require equipment, and, as far as computer printouts are concerned, few historians have been trained in their use. One remarked that with his brain and training he couldn't handle them and must rely on others' interpretation. A few have obviously made the effort-one historian, for example, wanted to learn to program - but most seem simply to ignore the computer.

A problem that cuts across the various formats and was mentioned distressingly often is that of interlibrary loan. Interlibrary loan is particularly important to historians with their need of access to a wide range of material. The British survey of humanists found that two-thirds of the humanists' projects used interlibrary loan and that historians were most likely to use it. ${ }^{14} \mathrm{~A}$ disturbing dissatisfaction with it was revealed. Too often it is painfully slow - if an item can be obtained at all. Its restrictions can also cause difficulties. One Colonial American historian spoke of having waited five months to get something and then being allowed one week to read through 5,000 pages of handwritten court records on microfilm.

Another major area of inquiry was how historians discovered relevant published information. On the same scale of one to five, the respondents were asked to rate the various methods both for usefulness to their current research and for keeping informed on what is currently being published in their fields (table 3). Given the opportunity to indicate other sources, several mentioned published announcements, bookstores, and conferences.

Table 3 reveals much about the work habits of historians. For example, they do not have a well-developed invisible college as do scientists, but depend primarily upon printed sources of information. ${ }^{*}$ The absence of an invisible college can be attributed to two factors: the lack of institutional arrangements to develop contacts, which is closely related to

*The Bath survey found a very interesting difference between Oxbridge social scientists who relied on an informal network and others, most noticeably those in colleges of education, who did not. In this survey, those at universities with the top twenty-five graduate programs were more likely to consult with colleagues at their own institutions on their research than other historians, but were no more ready to discuss or correspond with acquaintances elsewhere. 
TABLE 3

Methods of Discovering Relevant Published Information

\begin{tabular}{llcr}
\hline \hline & $\begin{array}{c}\text { Usefulness for } \\
\text { Research }\end{array}$ & $\begin{array}{c}\text { Usefulness for } \\
\text { Current Information * }\end{array}$ & $\begin{array}{c}\text { Rank Order } \\
\text { in Bath Survey }\end{array}$ \\
\hline Abstracts or indexes & $3.17(5)$ & $2.93(5)$ & 3 \\
Consulting known expert & $2.87(8)$ & $2.65(9)$ & 2 \\
Discussion with colleague at own institution & $2.6(9)$ & $2.7(8)$ & 4 \\
Discussion or correspondence with acquaintances elsewhere & $3.14(6)$ & $3.14(4)$ & 6 \\
Library catalogs & $3.5(4)$ & $2.9(6)$ & 8 \\
Searching library shelves at own institution & $3.0(7)$ & $2.88(7)$ & 10 \\
Consulting librarian & $2.16(10)$ & $1.90(10)$ & 13 \\
Specialized bibliographies & $4.01(2)$ & $3.93(3)$ & 6 \\
Bibliographies or references in books or journals & $4.36(1)$ & $4.59(1)$ & 1 \\
Book review & $3.85(3)$ & $4.56(2)$ & 11 \\
\hline
\end{tabular}

-Figures in parentheses are rank order.

tIn the Bath survey publishers' lists ranked 5, accessions lists 9, and scanning other libraries' shelves 12 . These sources were not included on this survey.

money, and the relative unimportance of currency. Historians' sources remain relatively traditional: books, journals, and bibliographies. Their methods are also unsystematic: that book reviews rank as high as they do as sources of useful research references is indicative. It is also in their use of book reviews that historians differ most markedly from social scientists. It must be painful to librarians that consulting them is so rarely considered useful, although both the Bath and the Illinois survey found that librarians ranked at the bottom for social scientists, too. ${ }^{15}$ Why this sorry state of affairs? In fact, it seems more likely that historians simply do not consult librarians, rather than when they consult them they get unsatisfactory results. One historian said that, even though he ranked consulting the librarian at two in both research and current information columns, when he did consult a librarian he got five-plus help.

The historians' lack of use of abstracts and indexes is further evidence of their unsystematic approach. One can only agree with the Bath survey: "Researchers certainly use fewer bibliographical tools than would be helpful to them, and do not make the systematic and frequent use of abstracting tools required to ensure good coverage of their topics and at the same time to minimize the possibility of missing important material." 16 The survey of English humanists reached a similar conclusion: there are a few scholars who appeal for better guides and bibliographies, but there is generally little consideration of information services or wish for them. ${ }^{17}$ The Illinois social science faculty also avoided subject bibliographies and secondary information sources, preferring to rely on bibliog- raphies and footnotes in journals or books to find references. ${ }^{18}$ The results of a question asking which indexing and abstracting services they had used for their current research suggest that use may be even less than indicated in table 3 . For example, why did so many American historians claim to have used Historical Abstracts, which contains no material on American history? The results of the indexing and abstracting question are tabulated in table 4.

For a librarian, the most startling result of this question has to be the heavy use of the Readers' Guide. Worthy as it is, much as we cherish it, the Readers' Guide is not an index to scholarly material. Until 1978 the only scholarly historical journal it indexed was the American Historical Review; in 1978 the index dropped even that. Some use of the Readers' Guide can be accounted for if it is used as a source of primary material, but this applies only to United States topical and twentieth-century historians. Unquestionably this result must be seen as a tribute to effective library orientation by school librarians - and the failure of university librarians to extend the scholars' knowledge.

Some of the response to this question cannot be shown in table 4. A number of historians went out of their way to say that they never used indexes or abstracts; many considered them irrelevant. Only one individual said that his nonuse was probably because he never learned how. The questionnaire allowed space for the respondents to write in other indexes or abstracts. A few took the opportunity to do so and for the most part their choices covered a very wide range, from P.A.I.S., the Revue d'histoire ecclésiastique 
TABLE 4

Indexing and Abstracting Services Used for Current Research

\begin{tabular}{|c|c|c|c|c|c|c|c|c|}
\hline & AHL & BHI & HA & $\begin{array}{l}\text { Hum } \\
\text { Ind }\end{array}$ & IBZ & RG & SSCI & $\begin{array}{l}\text { Soc Sci } \\
\text { Ind }\end{array}$ \\
\hline United States Topical & 9 & & 5 & 3 & & 10 & 2 & 4 \\
\hline United States Colonial Period & 16 & 2 & 6 & 8 & & 11 & 1 & 2 \\
\hline United States Nineteenth Century & 17 & 1 & 9 & 7 & & 13 & 5 & 5 \\
\hline United States Twentieth Century & 18 & & 13 & 5 & & 20 & 7 & 10 \\
\hline United States General & 20 & & 17 & 8 & 2 & 23 & 4 & 10 \\
\hline Art/Architecture & 1 & & 3 & 2 & 3 & 3 & & \\
\hline Miscellaneous & 2 & & 4 & & 1 & 3 & & 3 \\
\hline Music & & & & 2 & 1 & 2 & 2 & 1 \\
\hline Science/Technology & & 1 & 3 & & 3 & 3 & 1 & 1 \\
\hline Europe General & 1 & & 8 & 4 & 3 & 3 & 1 & 3 \\
\hline Great Britain & & 6 & 7 & 4 & & 9 & 3 & 4 \\
\hline Continental Europe & & & 8 & 4 & 6 & 5 & 2 & 2 \\
\hline Eastern Europe & & 1 & 9 & 3 & 5 & 3 & 2 & 5 \\
\hline Medieval & & & 5 & 4 & 2 & 3 & & 2 \\
\hline Classical & & 1 & 2 & 1 & & 3 & & 2 \\
\hline Far East & & 1 & 4 & 1 & & 5 & 2 & 3 \\
\hline Middle East & & & 2 & 1 & 2 & 4 & 2 & 2 \\
\hline $\begin{array}{l}\text { Africa } \\
\text { India }\end{array}$ & & 1 & 1 & 1 & & 1 & 2 & 2 \\
\hline Canada & & & 1 & 2 & & 1 & 1 & 2 \\
\hline Oceanic & & & & & & & 1 & 1 \\
\hline Latin America & 2 & & 6 & 6 & & 7 & 5 & 9 \\
\hline Totals & 86 & 15 & 113 & 66 & 28 & 132 & 45 & 73 \\
\hline
\end{tabular}

Abbreviations used:

AHL America: History and Life

BHI British Humanities Index

HA Historical Abstracts

Hum Ind Humanities Index

and Recently Published Articles to OCLC, Dissertation Abstracts, and the New York Times Index. Only four groups emerged with any strong preference for an index or abstract: the art historians with RILA (Répertoire international de la littérature de l'art), the music historians with RILM (International Repertory of Music Literature), the historians of science with the Isis bibliography, and the Latin American historians with the Latin American Handbook.

This result, together with table 4 , makes it clear that historians find most useful (and use) those sources that are directly targeted to their interests. This conclusion is supported by their response to a question asking which of the periodicals they subscribed to they found most useful. The journals for which a clear preference was shown were those with a relatively limited subject scope: the Journal of American History was favored by all groups of American historians except by the Colonial historians who preferred the William and Mary Quarterly; the Hispanic American Historical Review was the favorite of Latin American historians; the Journal of African History of African historians; the
IBZ Internationale Bibliographie der Zeitschriftenliteratur RG Readers' Guide

SSCI Social Sciences Citation Index

Soc Sci Ind Social Sciences Index

Journal of Asian Studies of Far Eastern historians; and the Slavic Review of East European historians. The only exception to this pattern was the British historians: their preference was for the American Historical Review, a general journal that pays no special attention to British history. These responses indicate, too, that very highly specialized journals are not the most valued. Even historians whose research specialty had a journal rarely chose it, preferring the more general. These reactions can be explained because what historians value most in their journals are the book reviews. By showing how historians approach their craft, these responses also provide important evidence on how information systems must be organized if the historian is to be reached.

The question on indexes and abstracts made an effort to find out which sources the historians found troubling and the nature of the trouble. Little useful information was obtained on the second part and the conclusion is inescapable that these scholars do not use their sources very critically. It also suggests that they would have more complaints if they understood them better or used them more 
often, as it was the most heavily used formats that elicited the most complaints. The two indexes that the highest percentage found difficult to use were the Internationale Bibliographie der Zeitschriftenliteratur and the British Humanities Index, figures that must be attributed to unfamiliarity. The $I B Z$ is a perfectly straightforward dictionary index and, although a German publication, has instructions in English and cross-references from English terms. There is nothing particularly noteworthy about the British Humanities Index. The Social Sciences Citation Index, on the other hand, which is genuinely complicated, ranked only third. There was, in addition, a suspicious disparity between America: History and Life with which 17.4 percent reported difficulty and Historical Abstracts with which only 11.5 percent of the users claimed difficulty. The two sources are organized in an almost identical fashion.

The historians were asked to assess the relevance of abstracts compared to simple author and title entries as references for their research. The results of this question speak for themselves (table 5). It should be noted, however, that their opinion seems to have changed, or at least become more definite, in the last decade, perhaps because the creation of America: History and Life and Historical Abstracts has familiarized them with abstracts. When American historians were surveyed in the late 1960 s few requested annotations of citations and most stated that they did not consider such evaluations useful. ${ }^{19}$

Table 6 presents the results of a question in which the historians were asked how often they accidentally discovered material for their current research by various means. There was one respondent who said that accidents shouldn't happen in well-planned research, but most seem to have experienced them. The most striking feature of table 6 is that it confirms the absence of an invisible college. It shows yet again that historians work in relative isolation with only a rudi-

TABLE 5

VAlue of ABstracts

\begin{tabular}{llcc}
\hline \hline & $\begin{array}{c}\text { About } \\
\text { the Same }\end{array}$ & $\begin{array}{c}\text { Somewhat More } \\
\text { Satisfactory }\end{array}$ & $\begin{array}{c}\text { Much More } \\
\text { Satisfactory }\end{array}$ \\
\hline Stieg survey & $23.7 \%$ & $46.4 \%$ & $29.9 \%$ \\
Bath survey* & $19 \%$ & $40 \%$ & $41 \%$ \\
\hline
\end{tabular}

-The Bath survey also had a category worse than author-title entry that accounted for $1 \%$ of the total.
TABLE 6

ACCIDENTAL DisCovery

\begin{tabular}{|c|c|c|c|}
\hline & $\begin{array}{c}\text { Rarely or } \\
\text { Never }\end{array}$ & Occasionally & Frequently \\
\hline Wandering along & & & \\
\hline library shelves & 37 & 179 & 108 \\
\hline Scanning current & & & \\
\hline $\begin{array}{l}\text { periodicals } \\
\text { Looking up a } \\
\text { given reference } \\
\text { and spotting }\end{array}$ & 8 & 152 & 173 \\
\hline something else & 16 & 153 & 151 \\
\hline $\begin{array}{l}\text { Receipt of } \\
\text { offprints }\end{array}$ & 171 & 114 & 31 \\
\hline In book shops & 184 & 117 & 22 \\
\hline $\begin{array}{l}\text { In conversation } \\
\text { with colleagues }\end{array}$ & 44 & 201 & 78 \\
\hline
\end{tabular}

mentary informal communications network. It also shows that although they depend on printed sources, they seldom frequent bookstores, perhaps because scholarly bookstores are few and far between.

The group was also asked how important it was for their research that they know very soon after publication what is published. Table 7 suggests that it is more important than has hitherto been assumed.

Another cluster of questions related to foreign languages. The scholars were asked which languages they read, if they attempted to read regularly the literature relating to their field in those languages, and how they dealt with references in foreign languages. Not surprisingly, language requirements notwithstanding, the majority (58 percent) of historians do not attempt to keep up with research published in foreign languages. A surprising number do not even read languages that would seem indispensable. There are Middle Eastern historians who know no Arabic, East European scholars who do not read Russian. At that, they do better than the British social scientists, only one-third of whom regularly scanned foreign language material. ${ }^{20}$ The only exceptions to this pattern were the various European historiansmedievalists, French historians, German, Russian, etc. - and the Latin American historians. How valid the response was, however,

TABLE 7

CuRRENCY

\begin{tabular}{llll}
\hline \hline & $\begin{array}{c}\text { Very } \\
\text { Important }\end{array}$ & $\begin{array}{c}\text { Moderately } \\
\text { Important }\end{array}$ & $\begin{array}{c}\text { Not Very } \\
\text { Important }\end{array}$ \\
\hline Stieg survey & $40.7 \%$ & $47.8 \%$ & $11.5 \%$ \\
Bath survey & $46 \%$ & $39 \%$ & $15 \%$ \\
\hline
\end{tabular}


must be in some doubt. It was extremely rare that any historian of any kind subscribed to a foreign periodical. This means that historians are dependent upon library copies, a fact that has to cast doubt upon the regularity of their keeping up. The same groups that claimed to keep up with research published in foreign languages were also an exception in that they tended to have less reluctance to look up references in the languages they knew. Other historians expressed greater hesitation.

The results of a question that asked how the individual dealt with a reference to an item in a language he did not read are shown in table 8. There was no obvious difference among the various groups of historians.

The final question on languages inquired if the historian felt that his research had been restricted or constrained in any way because of the language problem. As can be seen in table 9 , in all categories few did.

These results, like most of the results of this survey, must be interpreted in the light of a definition of research. Given that most doctoral degree programs in history still retain a language requirement, it is fair to say that, in the abstract at least, historians consider foreign scholarship important. Yet their practice has to raise serious questions for the librarians of hard-strapped research libraries. With the exception of European and Latin American historians, they seem to make little use of materials in foreign languages and, what is more, rarely miss it.

The final question asked what, if any, special information problems had arisen in the course of their present research. For convenience, these responses can be divided into those problems for which the librarian can provide assistance and those over which he or she has no influence. In this second category are problems such as lack of time and money for research, distance from a good research library, lack of knowledge of a language, and the fact that needed material doesn't exist or that it is of questionable reliability. Few historians were as philosophical as the scholar
TABLE 9

Research Restriction Because of Language Problem

\begin{tabular}{cccc}
\hline \hline None & Slightly & Moderately & Substantially \\
\hline 138 & 136 & 42 & 18 \\
\hline
\end{tabular}

who commented about information gaps and missing points of view: "I suspect that this troubles every scholar who deals with noteworthy topics."

There is however, one category of nonexistent material toward which librarians and archivists do bear a measure of responsibility. One nineteenth-century American historian had found the destruction of the original census returns a real handicap. A social historian, interested in social science data, finds that much is being destroyed after it is used for the purpose for which it was originally collected. Another historian considered the wholesale cancellation of subscriptions very harmful if it is continued and a threat to all scholars.

Other library and information problems the historians cited were restrictions on physical access, such as failure to declassify documents, lack of guides of all kinds, ranging from bibliographies of newspapers to guides to individual archival repositories, and, frequently, interlibrary loan. A Far Eastern historian finds the bibliographic control over nonroman alphabet languages inadequate and a Latin American historian felt that American libraries lacked people with enough linguistic skills to handle research requests. On the whole, these special problems were very similar to those found by the Bath study. British social scientists most commonly complained of physical access to and availability of information, published or unpublished.

From this survey it is clear that there is one group that has information problems requiring special consideration: the historians in small colleges. There are many, and many of them are making a real effort to carry on research. Yet, it is an inescapable fact that

TABLE 8

Response to ReFerence in Foreign Language That Historian Does Not Read

\begin{tabular}{lcccc}
\hline \hline & $\begin{array}{c}\text { Try to Get } \\
\text { Translated }\end{array}$ & $\begin{array}{c}\text { Search for Summary } \\
\text { or Abstract }\end{array}$ & $\begin{array}{c}\text { Try to Get } \\
\text { Gist on Own }\end{array}$ & Ignore \\
\hline Stieg survey & $30.3 \%$ & $21.7 \%$ & $34.7 \%$ & $13.3 \%$ \\
Bath survey & $15 \%$ & $30 \%$ & $27 \%$ & $28 \%$ \\
\hline
\end{tabular}


research needs go far beyond the capacities of small college libraries. Ultimately, the solution to their problems will be the realization of the goal of NCLIS: equal access to information for all Americans. In the meantime, however, for those who do not have convenient access to a research library there is no happy solution available. In the words of one historian, "When you are at a small college, almost everything has to come on loan," and another completed that with the statement, "Interlibrary loan is a very poor substitute for a well-developed collection." The unsolicited comments of those in this position revealed a strong sense of frustration.

The information obtained in this survey can be related to that found by the two citation studies in history. On the question of the formats from which the historian gets his information, it generally confirms and often explains what Jones, Chapman, and Woods found about English history. Books are most heavily used, followed closely by serials. They suggest, and it would not conflict with these findings, that periodical use is increasing. ${ }^{21}$ Theses and newspapers are relatively little used. There is greater contrast with the McAnally study, perhaps because patterns of research have changed since the sources for his data were produced. He found, for example, fairly heavy use of newspapers and considerable, though declining, use of government publications. ${ }^{22}$

Another topic covered here that Jones, Chapman, and Woods touch on is foreign language. They found very little use of materials in any language other than English by those who wrote of English history. ${ }^{23}$ The situation is less certain in the case of American history, but McAnally's table, analyzing by place of publication, certainly suggests a similar lack of use of non-English language materials. ${ }^{24}$

Jones, Chapman, and Woods make some extremely interesting observations on the dispersion of journal titles. They suggest that, although historians use a very wide range of journals, they concentrate their use on a much smaller proportion of the literature than has hitherto been supposed. They find that 75 percent of all journal needs can be satisfied by 25 percent of the titles cited. This survey had no question that could confirm or disprove this suggestion, but both the sub- scription patterns and index use of the respondents hint that they are probably right. The subscription patterns undoubtedly confirm, however, that they are right when they say that the range of journals used depends on the period and type of history studied. ${ }^{25}$

It is always easier to describe a problem than to find a cure, and the findings presented in this article are no exception. Both historians and librarians have to feel embarrassment over the picture that emerges. But how can these behavior patterns be changed? Historians and librarians will have to work hard and work together.

One first step must be some fundamental changes in historians' attitudes. To begin with, they must recognize that there is a problem. Too often professors grade their students solely on what use has been made of material, rather than take into account relevant material that has not been found. ${ }^{26}$ The budding scholar is hardly ever required to use what ought to be the tools of his trade nor does he often become conscious of potential inadequacy. Only in rare instances, such as on his dissertation or when he submits an article to a refereed journal, can a scholar hope to receive such criticism. And even then it is not automatic. The dissertation adviser must himself be aware that something is missing that cannot be solved by "taking a look at Jones's book," and the referee must know the literature of the subject.

Other, more specific manifestations of the problem are easier to deal with. In the use of foreign language materials, for instance, there is a fairly simple change that would undoubtedly help: requiring a higher standard of competence in graduate school. Too many language examinations require only a passing familiarity rather than the ability to use a language effectively.

Courses in research methods present an ideal opportunity for teaching a student the bibliography of his field. Schools that do not require such a course of their history graduate students should, and existing courses that do not have a bibliographic component should be altered to include one.

The primary responsibility for solving the problem must, however, be taken by the librarian. Ultimately, we are talking about library use and this is the librarian's domain. No one should know better the information 
sources to be commanded. Promoting library use is a central tenet of our professional faith. Bibliography is our professional expertise.

The first step, again, is acknowledgment that there is a problem. As Jones, Chapman, and Woods concluded their citation study, “. . . librarians ought not to be complacent about the type of service they provide for historians. Perhaps the fact that academics often distrust the ability of the librarians to provide the service they require is an unconscious recognition that they are not receiving the service they need from today's libraries." 27

Once the librarian decides to change these conditions, it becomes necessary to consider ways and means. Here, academic librarians can learn from their colleagues in other types of libraries. Urban public librarians have made efforts to reach a large group of nonusers, and special librarians are generally considered to be the most successful at helping their patrons. What urban public and special librarians have in common is aggressiveness. Neither waits for the patron to come to the library. Both are actively involved at all stages in the seeking and use of information. They place a greater emphasis on finding out what the patron thinks he needs (and providing it), regardless of library traditions, than do academic librarians. Both attach great importance to providing the information in the format most convenient to the user.

Academic and research librarians can also profit by intensifying some of their existing efforts. Most colleges and universities have at least some program in bibliographic instruction. Through properly designed bibliographic instruction programs future scholars can learn to use information resources effectively. A bibliographic instruction session may also have unintended side effects: the faculty member who chooses to sit in while a librarian provides such instruction to his or her class may pick up something useful for his or her own work.

The existence of library committees and the involvement of faculty with book selection provide other, less direct, opportunities to increase scholars' understanding of the problems and potentials of libraries. Committees can be used as a forum; the book selection process presents many occasions for conveying information. Both develop personal contact, not a particularly innovative or exciting method, but one that can be extremely effective. Just knowing someone to turn to in an institution makes it less intimidating - and we must remember that for uninitiated users libraries can be very intimidating.

Another factor that can be important in altering the character of the scholar's use of the library is the educational background of the librarian. It must be recognized that in order to provide effective reference service to scholars, subject knowledge is as crucial as professional knowledge, or perhaps subject knowledge is an integral part of professional knowledge. This is not to say that a librarian needs to have a Ph.D. in German history to help a German historian, but he does need to be a scholar in his own right as Jacques Barzun urges. ${ }^{28}$ To be considered a scholar, he must have a strong subject background in a related if not the same field, and a good general education. The spread of bibliographers with in-depth subject knowledge is a hopeful sign of change in this area, as is the increasingly common practice of requiring advanced subject work for other types of librarians in research libraries.

When all the evidence is added up, it is clear that too often historians fail to use existing sources of information. Their reasons for this are various: the historian may know that something exists but be unwilling to make the effort to use it; he may know it exists but be unable to obtain it, or he may be unaware that it exists. Whatever the reason, however, the final result is the same: a less good book or article is written, a less good class is taught than could be. Knowledge has suffered.

\section{REFERENCES}

1. For example, the pioneering work of P. L. K. Gross and E. M. Gross, "College Libraries and Chemical Education,” Science 66:385-89 (Oct. 1927).

2. Bath University Library, "Investigation into
Information Requirements of the Social Sciences" (Research Report 1: Information Requirements of Researchers in the Social Sciences [June 1971]).

3. Cynthia Corkill and Margaret Mann, Infor- 
mation Needs in the Humanities: Two Postal Surveys (Occasional Papers 2; British Library Research and Development Department Report, no.5455) (University of Sheffield, Centre for Research on User Studies, 1978). Microfiche.

4. Dagmar Horna Perman, ed., Bibliography and the Historian: The Conference at Belmont of the Joint Committee on Bibliographical Services to History, May 1967 (Santa Barbara, Calif.; Washington, D.C.: Clio, 1968).

5. Patricia Stenstrom and Ruth B. McBride, "Serial Use by Social Science Faculty: A Survey," College and Research Libraries 40:426-31 (Sept. 1979).

6. Robert N. Broadus, "The Literature of the Social Sciences: A Survey of Citation Studies," International Social Science Journal 23:236-43 (1972).

7. Lois Bebout, Donald Davis, Jr., and Donald Oehlerts, "User Studies in the Humanities: A Survey and a Proposal," $R Q$ 15:40-44 (Fall 1975).

8. Arthur Monroe McAnally, "Characteristics of Materials Used in Research in United States History" (Ph.D. Dissertation, University of Chicago, 1951).

9. Clyve Jones, Michael Chapman, and Pamela Carr Woods, "The Characteristics of the Literature Used by Historians," Journal of Librarianship 4:137-56 (July 1972).

10. Directory of American Scholars, v.1: History (7th ed.; New York and London: Bowker, 1978).

11. Jack Gourman, The Gourman Report: A Rating of Graduate and Professional Programs in American and International Universities. (Na- tional Educational Standards, 1980), p.31.

12. Behavioral and Social Sciences Survey, History Panel, History as a Social Science (Englewood Cliffs, N.J.: Prentice-Hall, 1971).

13. Corkill and Mann, Information Needs, p.86.

14. Ibid., p.26, 55 .

15. Bath University Library, table 71; Stenstrom and McBride, "Serial Use," p.42.

16. Bath University Library, p.91.

17. Corkill and Mann, Information Needs, p.56.

18. Stenstrom and McBride, "Serial Use," p.428-29.

19. Perman, Bibliography and the Historian, p.17.

20. Bath University Library, p.140-51.

21. Jones, Chapman, and Woods, "Characteristics of the Literature," p.152.

22. McAnally, "Characteristics of Materials," p.37.

23. Jones, Chapman, and Woods, "Characteristics of the Literature," p.146.

24. McAnally, "Characteristics of Materials," p. 60 .

25. Jones, Chapman, and Woods, "Characteristics of the Literature," p. 145.

26. James A. Kennedy, Thomas G. Kirk, and Gwendolyn A. Weaver, "Course-Related Library Instruction: A Case Study of the English and Biology Departments at Earlham College," Drexel Library Quarterly 7:289 (July/ Oct. 1971).

27. Jones, Chapman, and Woods, "Characteristics of the Literature," p.145.

28. Jacques Barzun, "The Scholar Looks at the Library," College of Research Libraries 7:116 (April 1946). 